\title{
A DUMUZI ÉS ĜEŠTINANNA CÍMÜ MÍTOSZ*
}

\begin{abstract}
A Dumuzi és Geštinanna című szöveg a sumer elbeszélő költemények problémás darabjai közé tartozik. A szokatlan megfogalmazások hátterében az állhat, hogy a szöveg ókori szerkesztője Dumuzi isten történetének problémáit a narratíván belül próbálta kommentálni. A szöveg „szerzője” nem explicit módon fogalmazta meg a teológiai kérdéseket, hanem hermeneutikai technikákkal juttatta ezeket kifejezésre: például mely ékjelekkel írjon szavakat, hogy azok Dumuzi lényegére utaljanak. Több helyen szokatlan fordulatokat használtak, amelyeknek intertextuális vonatkozásai lehetnek: ezek Dumuzi isten és a király, illetve Dumuzi és a felesége kapcsolatával hozhatók összefüggésbe.

Kulcsszavak: Dumuzi-Tammuz, sumer irodalom, hermeneutika, intertextualitás, vallás az óbabiloni korban
\end{abstract}

A Dumuzi és Ĝeštinanna (UET 6/11) ${ }^{1}$ elnevezésű mitikus elbeszélést a sumer irodalom legfurcsább művei között tartják számon. ${ }^{2}$ A szöveg nyelvezete nem könnyü, ritka szavakat használnak benne, Dumuzi isten új, különleges epithetont kap, jóllehet a történet a szokásos: Dumuzi isten (a sémi Tammuz) jól ismert mítoszával állunk szemben. Röviden összefoglalva arról van szó, hogy Inana, a mezopotámiai Vénusz istennő lemegy az alvilágba, de visszatér onnan. Mivel a halálból senki sem jöhet vissza következmények nélkül, helyettest kell találnia, akit maga helyett az alvilágba küldhet. A helyettes a férje, Dumuzi, a pásztoristen lett. Dumuzi megpróbálja elkerülni a sorsát, menekül a démonok elől, imádkozik a napistenhez, hogy segítsen neki, de mindhiába. A démonok elfogják és elviszik. A mű Dumuzi nővérének, Geštinannának a siralmával végződik, aki a bátyja keresésére indul.

Dumuzi halálának alaptörténete széles körben ismert és híres volt az ókori Mezopotámiában, még egy Dumuzi istenről elnevezett hónap is volt a naptárban. A legnépszerübb és leghosszabb elbeszélés, a Dumuzi álma 82 kéziratban maradt fenn, 260 sor hosszú, és a kéziratszámból következtetve valószínűleg az írnokképzés tananyaga volt. ${ }^{3}$ A történetet a Dumuzi és Ğeštinanna (73 sor) és a Dumuzi álma című szövegen kívül

* A British Museumba tett tanulmányutat az ELTE Tehetséggondozási Tanácsa támogatta.

${ }^{1}$ C. J. Gadd - S. N. Kramer: Ur Excavations Texts VI: Literary and Religious Texts, First Part (Ur Excavations Texts VI/1) 1963. UET 6/11.

${ }^{2}$ A. J. Ferrara: UET 6/1 11: Dumuzi and Geštinanna. A Heuristic Reappraisal. In: Gazing on the Deep. Ancient Near Eastern Studies in Honor of Tzvi Abusch. Eds. J. Stackert et al. Bethesda 2010. 27-47.

${ }^{3}$ Legutóbbi kiadása B. Alster: Dumuzi's Dream. Aspects of Oral Poetry in a Sumerian Myth. Copenhagen 1972 . 
legalább tíz másik fennmaradt mü mutatja be, többé-kevésbé hasonló módon. ${ }^{4} \mathrm{~A}$ müvekben bizonyos részleteknél eltérhet az alaptörténet (például Dumuzit banditák ölik meg vagy démonok viszik el), vagy a megfogalmazás módján változtatnak (műfajoktól és előadásmódtól függően szerkesztik meg a szöveget, vagy a szüzsé, az események sorrendje, részletessége más). A Dumuzi és Ĝeštinanna legelső sora in medias res szereplőbeszédet bevezető formula: „A kis galla-démon kinyitotta a száját, és a nagy galladémonhoz szólt." Prológus, bevezetés nincs. Dumuzi húga, Ġeštinanna beszéde közben, az utolsó sorban mintha a mondanivaló közepén abbahagyták volna a szöveg írását, és húztak a tábla alján egy vonalat. A történet néhol szinte szó szerint megegyezik más Dumuzi-elbeszélések megfogalmazásával, máshol viszont szinonimákkal, hasonló jelentésű szavakkal adták vissza ugyanazt, vagy az események ok-okozati, és így időbeli sorrendje tér el a többi Dumuzi-történettől.

Dumuzi és Ĝeštinanna eddig csak egy tábláról ismert, Ur városában ásták ki, a Broad Street 1. alatt álló házból, a padlót feltöltő sittből. ${ }^{5}$

A szakirodalomban az eddig megjelent tanulmányok fő kérdése az volt, hogy mi Dumuzi és Ĝeśtinanna viszonya a népszerübb elbeszélésekhez, Inana alvilágjárásához és Dumuzi álmához. Három javaslat született:

1. A Dumuzi és Ĝeštinanna (72 sor) az Inana alvilágjárása szöveg (kb. 450 sor) rövidebb összefoglalója vagy kivonata. ${ }^{6}$

2. A Dumuzi és Geštinanna az Inana alvilágjárása szöveg vége, Ur városában ilyen formában ismerték.?

3. A Dumuzi és Ĝeštinanna egy önálló verzió, csak más szereplő szempontjából mutatja be az eseményeket. W. Sladek szerint Inana alvilágjárása Inana szempontját, Dumuzi álma Dumuziét, Dumuzi és Geštinanna pedig Geštinannáét helyezi az előtérbe. ${ }^{8}$

A harmadik javaslat nem elég meggyőző, mert a 73 soros Dumuzi és Ĝeštinanna történetből 35 sorban a démonok az igék alanyai, így a történet legprominensebb sze-

${ }^{4}$ Alster: i. m. (3. jegyz.); W. Sladek: Inanna's Descent to the Netherworld. Ann Arbor 1974; K. Volk: Die Balaĝ-Komposition úru àm-ma-ir-ra-bi. Rekonstruktion und Bearbeitung der Tafeln 18 (19'ff.), 19, 20 und 21 der späten, kanonischen Version. Stuttgart 1989; M. E. Cohen: Sumerian Hymnology: The Eršemma Cincinnati 1981. no. 97, no. 88, no. 165, no. 60; J. A. Black: Dumuzid and His Sisters. Orientalia 73 (2004) 228-234; S. N. Kramer: Cuneiform Studies and the History of Literature: The Sumerian Sacred Marriage Texts. Proceedings of the American Philosophical Society 107 (1963) 485-527; Th. Jacobsen - S. N. Kramer: The Myth of Inanna and Bilulu. JNES 12 (1953) 160-188. Összefoglalva: M. M. Fritz: „...und weinten um Tammuz". Die Götter Dumuzi-Ama'ušumgal'anna und Damu. Münster 2003.

${ }^{5}$ D. Charpin: Le Clergé d'Ur au siècle d'Hammurapi. Paris 1986. 484.

${ }^{6}$ Kramer: i. m. (4. jegyz.); D. Katz: The Image of the Netherworld in the Sumerian Sources. Bethesda 2003. 289-300.

${ }^{7}$ Ferrara i. m. (2. jegyz.); Th. Jacobsen: The Harps that Once...: Sumerian Poetry in Translation. New Haven - London 1987. 226; B. Alster: Variations in Sumerian Myths as a Reflection of Literary Creativity. In: Narratives of Egypt and the Ancient Near East. Literary and Linguistic Approaches. Eds. F. Hagen et al. Leuven - Paris - Walpole 2011. 16.

${ }^{8}$ Sladek: i. m. (4. jegyz.) 28-33. 
replői közé tartoznak. Az első két elmélet mellett és ellen is lehet érvelni, mindenesetre a szövegről megjelent legújabb tanulmányban a szerző, Ferrara is csak egy verziónak tekinti: szerinte Ur városában ez volt az Inana alvilágjárárásának a vége. ${ }^{9}$ Többek között azért, mert a szöveg eleje és vége olyan, mintha egy kivágott részlet lenne. Máshonnan egyelőre nem került elő duplum. Mindemellett akár önálló szöveg, akár helyi verzió, tagadhatatlan, hogy eltér a standard Inana alvilágjárásától. Eltekintve a szöveghagyományozás részletekbe menő problematikájától, megmarad a kérdés, hogy egyáltalán miért fogalmazták újra Dumuzi jól ismert történetét? Mi volt a szöveg célja? Miért tartotta valaki szükségesnek, hogy írjon egy másik, kicsit eltérő mitikus elbeszélést, ami első pillantásra annyira nem is különbözik a Dumuzi álma és az Inana alvilágjárása történetektől? Vagy éppen miben és hogyan különbözik a többitől?

A hipotézisem a következő: a Dumuzi és Ĝeštinanna címủ mủ szerzője új, magasabb írnoki képzettséget igénybe vevő módon akarta megfogalmazni Dumuzi jól ismert történetét. A szöveg tizenhatodik soránál tűnt fel, hogy a sorban szereplő fegyvernevek, amelyeket a démonok Dumuzi arca felé tartanak, tartalmaznak egy bizonyos ékjelet, ami mind a három fegyvernévben ugyanúgy néz ki.

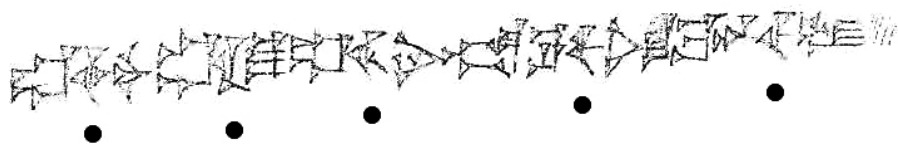

1. ábra. A szöveg 16. sora

Az alábbi átírásban a félkövérrel kiemelt szótagok egyeznek meg:

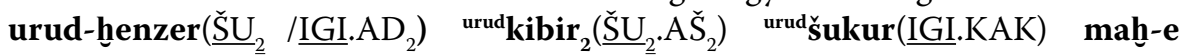

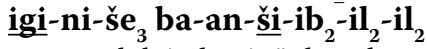

„alabárd, véső, hatalmas lándzsa meredt felé"

A fegyverek vagy a $\breve{S}_{2}$ vagy az IGI jeleket tartalmazzák - a tábla írásképén ugyanúgy néznek ki. Mindhárom szó egy ún. diri-kompozitum, ami azt jelenti, hogy egy szót több ékjellel írnak le, de ezek együttesét másképp olvassuk ki. Például a $\breve{S}_{2} \cdot \mathrm{A} \breve{S}_{2}$ ékjelekből álló diri-kompozitum olvasata kibir ${ }_{2}$. A trükk az, hogy a fegyvereket Dumuzi arca felé tartják, ami sumerül igi. Az írnok a sorhoz éppen az igi vagy igi kinézetủ jeleket (jelen esetben a $\breve{S}_{2}$ ) tartalmazó fegyverneveket válogatta össze. Az arc felé tartott fegyverek így már az írás szintjén, az elnevezéseikben magukban hordozzák az irányultságukat, az arc szótagot.

A szöveg megfogalmazója így az istenséghez kapcsolódó teológiai nézeteit a narratívába fogalmazta bele (lásd alább), de olyan módon, hogy a szöveg hermeneutikus ér-

\footnotetext{
${ }^{9}$ Ferrara: i. m. (2. jegyz.) 29.
} 
telmezési lehetőségeket tegyen lehetővé az egyes szavak ékjelein keresztül. ${ }^{10}$ Másrészt, különös hangsúlyt fektetett Dumuzi halálának okára és minőségére. Dumuzi halála ennek megfelelően egyfajta „rossz halál”, amit a felesége okozott. Nem minden szövegben jelenik meg ennyire explicit módon ez a nézet.

\section{Az ékírás mint irodalmi eszköz}

Az óbabiloni korban (Kr. e. 2000-1500) egyre gyakrabban találkozunk azzal a jelenséggel, hogy a standard megfogalmazásokat „kriptografikusra” cserélik. Ezzel a módszerrel vagy hermeneutikus értelmezési lehetőségeket építenek be a szövegbe, vagy csak egyszerủen írnoki kreativitásról van szó. ${ }^{11}$ A komolyabb teológiai gondolatoktól az írnoki viccekig terjed a repertoár, ${ }^{12}$ mindenesetre a trükkök észrevételéhez valószínűleg magasabban képzett írnoknak kellett lennie a tábla olvasójának.

Az óbabiloni sumer irodalmi szövegekben három ilyen írnoki technika különböztethető meg, ami a szövegek irodalmi értékét és kimunkáltságát növelte: a jelek speciális, rendhagyó használata, a hangzással való játék és az intertextualitás - jelen tanulmányunkhoz kapcsolódóan - például lexikális listákkal. ${ }^{13}$

Az ékírás legfontosabb jellemzője a homofónia és a polifónia. A homofónia azt jelenti, hogy eltérő ékjelek ugyanolyan olvasattal rendelkeznek. Például a /lu/ jelentheti azt, hogy „juh”, „ember” és azt, hogy „összezavar”. Mindegyik /lu/ hangzású szóra külön ékjel van: a juh a lu ékjel, az ember a lu $\mathbf{l}_{2}$, az összezavar a $\mathbf{l u}_{3}$.

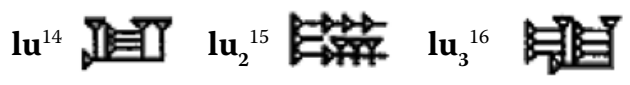

2. ábra. /lu/ olvasattal rendelkező jelek

${ }^{10}$ E. Frahm: Babylonian and Assyrian Text Commentaries. Origins of Interpretation. Münster 2011. 28: a szövegeket csak kulcsszavakkal magyarázták.

${ }^{11}$ Nem minden előzmény nélküli a módszer. Ehhez lásd a kora dinasztikus ún. ud-gal-nun szövegeket: W. G. Lambert: Studies in UD.GAL.NUN. OA 20 (1981) 81-97; J. Krecher: Sumerische Literatur in der FaraZeit: Die UD.GAL.NUN-Texte I. BiOr 35 (1978) 155-160. Óbabiloni sumer példákhoz legújabban M. Geller J. C. Johnson: The Class Reunion. An Annotated Translation and Commentary on the Sumerian Dialogue Two Scribes. Leiden - Boston 2015; J. Crisostomo: Language, Translation, and Commentary in Cuneiform Scribal Practice. JANEH 5 (2018) 41-56; E. Jiménez: „As Your Name Indicates”: Philological Arguments in Akkadian Disputations. JANEH 5 (2018) 87-105.

${ }^{12}$ Lásd P. Michalowski: Where is AL? Humor and Poetics in the Hymn to the Hoe. In: Why Should Someone Who Knows Something Conceal It? Cuneiform Studies in Honor of David I. Owen on His 70th Birthday. Eds. A. Kleinerman - J. M. Sasson. Bethesda 2010; M. Civil: The Anzu Bird and Scribal Whimsies. JAOS 92 (1972) 271.

${ }^{13}$ Ha csak a sumer szöveget nézzük. Néhány szövegben az akkád fordítások is fontosak: Crisostomo: i. m. (11. jegyz.); Michalowski: i. m. (12. jegyz.).

${ }^{14}$ R. Borger: Mesopotamisches Zeichenlexikon. Münster 2004. 428, no. 812.

${ }^{15}$ Borger: i. m. (14. jegyz.) 357, no. 514.

${ }^{16}$ Borger: i. m. (14. jegyz.) 363, no. 555. 
A polifónia arra utal, hogy egy-egy ékjelnek több olvasata van. A DU ékjelet például kontextustól függően úgy is lehet olvasni, hogy de $\mathbf{d e}_{6}, \hat{\mathbf{g e n}}, \mathbf{r} \mathbf{r}_{2}, \mathbf{r e}_{6}, \mathbf{s ̌ a}_{\mathbf{4}}, \mathbf{t u m}_{2}$ stb.

Ebből a rendszerből adódik az ékírás páratlanul kreatív jellege. Az ékírás kezdetétől fogva kísérletezgettek a jelek, a jelentéseik, valamint az olvasatuk adta lehetőségekkel, és a jelek kialakulásánál is gyakran ezek a tényezők játszottak szerepet. ${ }^{17}$ Éppen emiatt nehéz a maga valójában az ékírásos irodalmat mint irodalmi szövegeket modern nyelveken bemutatni. Sok szövegnek az volt a legnagyobb irodalmi értéke, hogy az írnokok a táblán látták a jeleket, és az előttük olvasható jelekben felismerték a szövegben használt trükköket.

\section{A hangzás adta lehetőségekkel való játék}

A hangzás adta lehetőségekkel való játék humoros és komoly szövegekben egyaránt megtalálható. A legnevezetesebb példa az ókori sumer irodalmi tananyag tíz fő szövegének (ún. Dekád) egyike, a Kapa éneke. ${ }^{18}$ A szöveg a kapa, sumerül al hangzására rímelő -al- szótagokat tartalmazó szavakkal van tele, mint például a gal „nagy”, vagy lugal „király", illetve az igék prefixláncai az al- ragot tartalmazzák. ${ }^{19}$ A szöveget valószínűleg már az ókorban szándékosan homályosan fogalmazták meg, ezért hiteles fordításra a jelen keretek között nem vállalkozom (nem véletlen, hogy még mindig nincs teljes modern kiadása a münek). ${ }^{20} \mathrm{~A}$ Majom (vagy Ugubi) levele az anyjához viszont ugyanígy szemlélteti a rímekkel és félreérthető hangzásokkal való játékot. ${ }^{21}$

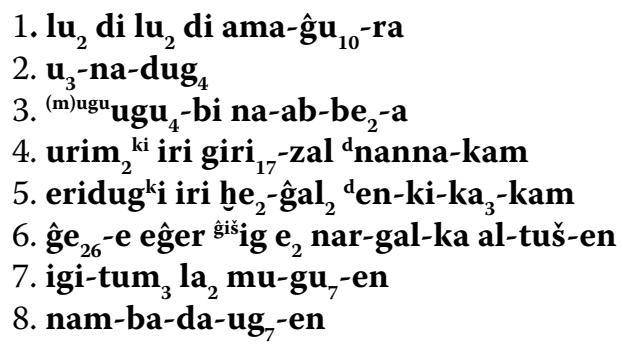

Vándor, vándor, az anyámnak mondd, így szól Ugubi (vagy a majom): Urim Nannáé, a boldogság városa, Eridu Enkié, a bőség városa. Én viszont itt ülök a főénekes ajtaja mögött, a kukkolás felemészt, nem akarok meghalni!

${ }^{17}$ Lásd 11. jegyz.

${ }^{18}$ Lásd D. O. Edzard: U 7804 // UET VI/1 26: „Gedicht von der Hacke”. In: Wisdom, Gods and Literature: Studies in Assyriology in Honour of W. G. Lambert. Eds. A. R. George - I. L. Finkel. Winona Lake 2000. 131-135.

${ }^{19}$ Michalowski: i. m. (12. jegyz.).

${ }^{20}$ G. Farber: Das Lied von der Hacke, ein literarischer Spass? In: Landwirtschaft im Alten Orient: ausgewählte Vorträge der XLI. Rencontre Assyriologique Internationale Berlin, 4.-8.7.1994. Hrsgg. H. Klengel - J. Renger. Berlin 1999. 369-373.

${ }^{21}$ A. Klevierman: Education in Early 2nd Millennium BC Babylonia. Leiden - Boston 2011. 276-277. 
A szöveg több rímet is tartalmaz: egyrészt a 4-5. sorokban van egy belső és egy sorvégi rím: a giri ${ }_{17}$-zal és a h. $\mathbf{e}_{2}$ - gal $_{2}$, illetve a Nannakam és az Enkika(m). Ezenfelül a város 'e/iri' szóra rímel a két sor: urim iri girizal és eridug iri heĝal. A hatodik sor a levél küldőjének a makogása: ĝ e ệer ig e... Nem tudom biztosan megmondani, hogy a 7-8. sorok igéinél is szándékosan van-e -ug-, illetve -gu- szótag: la muguen és nambadaugen, ami az ugubi „majom” szóra emlékeztethet, mindenesetre mindenképpen félrehallható a hatodik sorban az, hogy a levél éhenhalás szélén álló küldője az e nargal, vagy e Nergal mögött ül. Az előbbi a föénekes ajtaja, az utóbbi Nergal isten és az alvilág kapuja. M. Cohen, a szöveg egyik kiadója szerint a levél küldője nem majom volt, hanem egy Ugubi nevű ember ${ }^{22}$ - ez is majmot jelent, csak akkor gúnynév lehet. ${ }^{23} \mathrm{~A}$ szöveg viccnek volt szánva, cirkuszi majomra utaló allúziókkal, kétértelmü szavakkal, amelyek hangzása halandzsaszerü - elvégre Ugubi, a majom a főszereplő.

\section{Lexikális listák}

Sokféle oka lehet annak, hogy miért kerülnek be egyes szavak egy irodalmi mübe. A sumer irodalmi szövegeket gyakran „töltötték fel” olyan szavakkal, amelyeket lexikális listákból idéztek (vagy fordítva, lexikális listák összeállításai irodalmi szövegeken alapulnak). ${ }^{24}$ A Nanše és a madarak címü szöveg például rengeteg madárnevet sorol fel. N. Veldhuis, a szöveg modern kiadásának szerzője felhívta a figyelmet arra, hogy a szöveg ókori (és tulajdonképpen mai) tudományos értéke nem az ornitológiai megfigyelésekben rejlik, hanem a specializált szókincs reprezentálásában. Az írnokok célja az volt, hogy a sumer nyelvet és az írást minél magasabb szinten elsajátítsák, ebből kifolyólag különleges presztízse volt az archaikus és ritka szavaknak, valamint az ilyen szavakat tartalmazó listáknak és műveknek. Ezek képviselték a magasabb szakmai szintet. A Nanše és a madarak válogatott szókincse az ún. Kora dinasztikus madárlistából származik - ez a lista nem tartozott az alaptananyag korpuszába. ${ }^{25}$

A Dumuzi álma szöveg nem ilyen bonyolult. Dumuzi és Geštinanna említett 16. sorában viszont az első ékjel (urud-ḩenzer: $\mathrm{SU}_{2} /$ IGI.DIM) csak lexikális listákban fordult eddig elö, ${ }^{26}$ a második ( ${ }^{\text {urud }} \mathbf{k i b i r}_{2}: \breve{S}_{2} \cdot \mathrm{AS}_{2}$ ) szintén csak lexikális listákban, és egy sumer közmondásban. ${ }^{27}$

${ }^{22}$ M. E. Cohen: The „Monkey-Letter”: A Different Perspective. OrNS 45 (1976) 270-274.

${ }^{23}$ M. A. Powell: Ukubi to Mother... The Situation is Desperate. ZA 68 (1978) 194.

${ }^{24} \mathrm{~J}$. Crisostomo: Multilingualism and Formulations of Scholarship: The Rosen Vocabulary. ZA 106 (2016) 22-32.

${ }^{25}$ N. Veldhuis: Religion, Literature, and Scholarship: the Sumerian Composition Nanše and the Birds, with a Catalogue of Sumerian Bird Names. Leiden - Boston 2004. 55.

${ }^{26}$ Materials for the Sumerian Lexicon XV: 18: 146-149. sor; Materials for the Sumerian Lexicon XIV: 402: 198. sor.

${ }^{27}$ Materials for the Sumerian Lexicon XV: 136: 002-005. sor; Materials for the Sumerian Lexicon XIV: 194: 350. sor; ETCSL 6.1.03. 164. sor és ETCSL 6.1.02. Segm. B 16. sor. 
Jelek alapjelentésével való játék

A harmadik technika az ékjelek alapjelentését veszi figyelembe. Mindegyik ékjelnek van egy (vagy több) alapjelentése, ami egy fogalomra utal. Emellett több ékjel is rendelkezik ugyanolyan olvasattal, vagy egy ékjel több olvasattal (lásd a fentebb vázolt homofónia és polifónia jelenségét).

A cél az volt, hogy a megfelelő alapjelentésủ ékjelet jelenítsék meg a szövegben, és ne egy másik, ugyanúgy olvasható, de más formájú vagy alapjelentésű jelet. Az írás ezzel ezoterikus jelleget kaphatott: a megfelelően képzett írnok, akinek „volt szeme a látásra”, észrevette, hogy sumerül egy bizonyos módon hangzó sor milyen más olvasattal és így alapjelentéssel rendelkező ékjelekből épül fel. Annak ellenére, hogy egy sor egyféleképpen hangzott, írásban a jeleken keresztül mélyebb jelentést is közölt. Nem véletlen, hogy az ékírás elsajátítását ahhoz hasonlították, ahogy a diák szeme megnyílik:

Edubba C 33. sor: ${ }^{28}$

„mint kiskutyának, megnyitod a szemét, és embert faragsz belőlem”

Éppen ennél a sornál az egyik óbabiloni írnok élt is ezzel a technikával. A szöveg standard verziója sumerül ur-gir ${ }_{15}$ tur-gin $_{7}$ igi mu-e-bad(BAD)-bad(BAD) nam-lu $\mathbf{u}_{2}$-ulu $\mathbf{u}_{3}$ mu-e-ak. Az igi - bad "szemet kinyitni”, „látni” kifejezés kompozit ige, a „szem” IGI és a BAD „kinyitni” elemekből áll. A CBS 13106-os tábla írnoka viszont az igi - bad „szemet kinyitni”, „látni” kifejezést nem a szokásos BAD jellel írta, hanem az

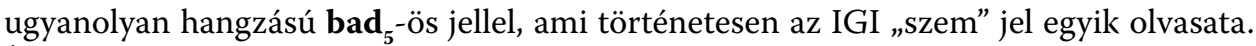
Így duplán utalt a szemre és a látásra. mu-e-ak.

CBS 13106 ${ }^{29}:$ ur-gir $_{15}$ tur-gin $_{7}$ igi mu-e-bad (IGI)-bad $_{5}$ (IGI) nam-lu nulu $_{3}$

A legtöbb olyan szöveg, ahol az olvasatok adta lehetőségekkel éltek, az első évezredből származik. ${ }^{30}$ Bizonyos akkád szövegeket szándékosan kriptografikusan fogalmaztak meg, hogy ezoterikus jelentést tudjanak közvetíteni, vagy meglévő szövegeket kommentáltak ilyen alapon. Számos kommentár maradt fenn így, például a Teremtéseposzról, ezen belül Marduk isten ötven nevéről ${ }^{31}$ vagy egészen eltérő müfajú szövegekről (ráolvasások, asztrológiai, jogi szövegek stb.). ${ }^{32}$

A jelen tanulmányban tárgyalt szöveg, a Dumuzi és Ĝě́tinanna is éppen emiatt érdekes. Ha jobban megnézzük a szöveg bizonyos sorait, észrevehetjük, hogy vagy rend-

${ }^{28}$ Egy iskolai életről szóló költemény.

${ }^{29}$ cdli.ucla.edu: cdli no. P268191: 14. sor.

${ }^{30}$ Frahm: i. m. (11. jegyz.); J. Krecher: Kommentare. In: Reallexikon der Assyriologie VI. Berlin - New York 1980-83. 188-191. A müfajra akkád szó is volt: șâtu és mukallimtu.

${ }^{31} \mathrm{~J}$. Bottéro: Les noms de Marduk, l'écriture et la 'logique' en Mésopotamie Ancienne. In: Essays on the Ancient Near East in memory of Jacob Joel Finkelstein. Ed. M. de Jong Ellis. Hamden 1977. 5-28; A. Livingstone: Mystical and Mythological Explanatory Works of Assyrian and Babylonian Scholars. Oxford 1986.

${ }^{32}$ Cuneiform Commentaries Project: ccp.yale.edu. 
hagyó módon írtak szavakat - és így a megfelelő ékjeleket használhatták -, vagy direkt olyan kifejezéseket használtak, amelyek már tartalmazták a nekik kellő szótagot. Az ékjelek használata alapján itt egészen sajátos mezopotámiai vallástörténeti jelenséggel van dolgunk: az óbabiloni teológia Dumuzi isten lényegét az ékjeleken keresztül ragadta meg. Mielőtt rátérek a Dumuzi és Geštinanna speciális jelhasználataira, rövid összefoglalót kell adnom a Dumuzit érintő vallástudományi kutatásokról, mivel a téma érinteni fogja ezt a területet.

Dumuzi (az akkád Tammuz) a meghaló pásztor, Inana istennő férje kétféle szövegtípusban jelenik meg. A szent nász szövegekben mint Inana istennő férje, ${ }^{33}$ illetve a haláláról szóló elbeszélésekben és siratókban. A Sumer Királylista is felsorol két Dumuzi nevű uralkodót, a pásztor királyt Badtibira városából és a kuarai halászt Urukból. ${ }^{34}$ Dumuzi kultuszának utolsó csúcspontja az óbabiloni korban volt. Később úgy tűnik, csökkent a jelentősége, valószínűleg maszkulin jellegének tökéletes hiánya miatt, ${ }^{35}$ ami a mezopotámiai királyi ideáltól távol állt.

A Dumuziról szóló vallástörténeti kutatások érzékletesen szemléltetik az elmúlt száz év vallástudományának irányzatait. Frazer Az aranyág és Adonis, Attis, Osiris című könyveinek hatására Dumuzi-Tammuzt először vegetációistennek tartották. ${ }^{36}$ Ebből kiindulva felmerült az a javaslat, hogy nem jelölheti-e esetleg a mezopotámiaiak feltámadásba és örök életbe vetett hitét. ${ }^{37}$ A Jézussal való párhuzamok nyilvánvalóan megjelentek: a mítosz része a három napon belüli feltámadás (legalábbis Inana, a felesége feltámadt), a barát árulása, a szenvedő kínzása és ruháitól való megfosztása, a pásztor epitheton stb. ${ }^{38}$ Nem véletlen, hogy - ha nem is hasonlította mindenki Jézushoz - Tammuz több szerző szerint is a legfőbb mezopotámiai istenség volt, az összes isten alapja és előképe, az örök élet vagy a termékenység férfiistene. Mindenki más csak az ő egyik aspektusa. $^{39}$

A nevének etimológiai elemzése Dumuzi feltételezhető eredetét vetette fel. Értelmezéstől függően ez a datolyapálma sarja, az új növekedő élet, az „igaz ifjú” lenne. ${ }^{40}$ A foglalkozása miatt Dumuzi a gabona vagy a juhok tejelése mögötti erőt is szimbolizálná. ${ }^{41}$ A szent nász szövegekből kiindulva a mezopotámiai uralkodóval is párhuzamba

${ }^{33}$ S. N. Kramer: The Sacred Marriage Rite: Aspects of Faith, Myth, and Ritual in Ancient Sumer. Bloomington 1969; Y. Sefati: Love Songs in Sumerian Literature. Critical Edition of the Dumuzi-Inanna Songs. Ramat Gan 1998.

${ }^{34}$ C.-A. Vincente: The Tall Leilān Recension of the Sumerian King List. ZA 85 (1995) 236-238.

${ }^{35}$ Th. Jacobsen: Toward the Image of Tammuz. History of Religions 1 (1962) 190-192: Intransitiveness.

${ }^{36}$ S. Langdon: Tammuz and Ishtar. A Monograph upon Babylonian Religion and Theology. Oxford 1914.

${ }^{37}$ M. Witzel: Tammuz-Liturgien und Verwandtes. Roma 1935; A. Moortgat: Tammuz, der Unsterblichkeitsglaube in der altorientalischen Kunst. Berlin 1949.

${ }^{38}$ Kramer: i. m. (33. jegyz.) 133: a könyv utolsó oldala; Moortgat: i. m. (37. jegyz.) 44.

${ }^{39}$ Witzel: i. m. (37. jegyz.) vii skk.; Moortgat: i. m. (37. jegyz.).

${ }^{40}$ Th. Jacobsen: The Treasures of Darkness. History of Mesopotamian Religion. New Haven - London 1976. 26.

${ }^{41}$ Jacobsen: i. m. (40. jegyz.) 25-26. 
állították, hogy ő az uralkodó előképe - egy himnusz párhuzamos sorában így is értelmezhető a neve. ${ }^{42}$ Mivel a róla szóló szövegek nagy része vagy a házasságát vagy a halálának siratását mutatja be, valamint Ezekiel könyve megemlíti a Tammuzt sirató nőket, „női vallásnak” is tartották a kultuszát, azaz a háttérbe szorított nők érzelmeinek kitombolásáról lenne ilyenkor szó. ${ }^{43}$ Ez utóbbi elmélet szerint Dumuzi kultusza népvallás jellegű, más tanulmányok viszont a Dumuzi körül összpontosuló „misztériumvallást” említik. ${ }^{44}$ Dumuzi kultusza kapcsán mind az - előbb is említett - legszélesebb körben elterjedt népvallás, mind a misztériumvallás fogalma felmerült. Az 1910-40-es évek szakirodalmának Tammuza, a „legfontosabb sumer isten” 1990-re sokat veszített az értékéből: Kutscher szerint a kultuszára a felajánlási listák alapján alig vannak utalások, és alig voltak templomai. ${ }^{45}$ Véleményem szerint a kijelentés kissé radikális: körülbelül 110 sumer himnuszból 30-at írtak Inana és Dumuzi szent nászáról, és a haláláról szóló szerzeményeket ebbe nem számoltam bele. ${ }^{46} \mathrm{~A}$ jelen tanulmány szempontjából legfontosabb elemzést Alster írta. Alster egyrészt elvetette a vegetációra való hivatkozásokat, egyszerüen azért, mert nincs rá forrás, másrészt kiemelte Dumuzi átmeneti jellegének fontosságát a van gennepi értelemben. ${ }^{47}$ Dumuzi, a pásztor és király egyszerre isten, de meg is hal, Inana istennő férje, de földi király. Az ő területe a puszta, ahol a nyájait legelteti, Mezopotámiában pedig a legerősebb köztes és átmeneti jelleggel rendelkező terület éppen a városon kívül elhelyezkedő pusztavidék. ${ }^{48}$

Visszatérve a Dumuzi és Geštinanna szövegéhez, röviden összefoglalva a következő nézeteket közvetíti a szöveg, amelyek más Dumuzi-szövegekre nem feltétlen jellemzőek, vagy legalábbis nem ilyen ezoterikus formában, mint alább látni fogjuk. Egyrészt Dumuzi halálának minőségét, a korai, családalapítás előtti halált, ami Mezopotámiában rendkívül szerencsétlen dolog. Burkoltabb formában az átkelés és átváltozás lényege is megjelenik, amelynek iránya a túlvilág. Végül a szövegben Inana a hibás Dumuzi haláláért: nem megfelelő dolgokat akart. Ezen belül két olyan sor is található a szövegben, amelyek intertextuálisan Dumuzi, a király és Inana istennő viszonyára utalnak. A mezopotámiai történelem korábbi időszakaiban Inana istennő és a király viszonya szoros volt, a király volt az istennő földi párja, és gyakran Dumuzival azonosították magukat

${ }^{42}$ Kramer: i. m. (4. jegyz.); J. Scurlock: "Images of Tammuz: The Intersection of Death, Divinity and Royal Authority in Ancient Mesopotamia”. In: Experiencing Power, Generating Authority: Cosmos and Politics in the Ideology of Kingship in Ancient Egypt and Mesopotamia. Ed.: Ph. Jones. Philadelphia 2013. 151-182.

${ }^{43}$ Fritz: i. m. (4. jegyz.) 353 skk. további szakirodalommal.

${ }^{44}$ A teljességre való törekvés igénye nélkül példák: Moortgat: i. m. (37. jegyz.) 34: „Mysteriumglauben”, 89: „mystische Glaube” 97: „Tammuz-Mysterium”, 110: „mysteriumreligiös”; Langdon: i. m. (36. jegyz.) 3.

${ }^{45}$ R. Kutscher: The Cult of Dumuzi. In: Bar-Ilan Studies in Assyriology Dedicated to P. Artzi. Eds. J. Klein - A. Skaist. Ramat Gan 1990.

${ }^{46}$ ETCSL alapján: etcsl.orinst.ox.ac.uk.

${ }^{47}$ Les rites de passage. 1909.

${ }^{48}$ Alster: i. m. (3. jegyz.) 14-15. 
ebben a szerepkörben. Az imént felsorolt dolgokat vagy a fentebb szemléltetett írnoki hermeneutikai technikákkal fogalmazták a szövegbe, vagy intertextuális allúziókkal.

A Dumuzi-szövegek ókori recepciótörténetének egyik legfontosabb eleme a halál oka volt. Az ókori szerzők fő kérdése, ami számunkra is a legnyilvánvalóbban megjelenik, az volt, hogy Dumuzi miért halt meg. Három verzió ismert:

1. Dumuzi halálának nincs ismert oka (Dumuzi álma).$^{49}$

2. Inana az oka, amiért lement az alvilágba (Inana alvilágjárása, ${ }^{50}$ Dumuzi és Geštinanna).

3. Dumuzi az oka, amiért nem gyászolta a feleségét, vagy hủtlen volt hozzá (Inana alvilágjárása, Úru ama irrabi balaĝ-himnusz). ${ }^{51}$

Dumuzi és Ĝeštinanna egészen nyíltan Inanát hibáztatja: a 13. sorban a narrátor kijelenti, hogy „Inana Dumuzit adta a kezükbe maga helyett”, majd Dumuzi elmeséli a sógorának, a napistennek, hogy Inana helyett kell meghalnia: „Ô lement az alvilágba, mivel ő lement az alvilágba, én helyettesnek az alvilágnak lettem adva.” Más szövegekben nem hivatkozik a feleségére, mint a halálának okára.

A halál oka mellett annak minősége is felmerül. A mezopotámiai kultúrában is léteztek jó és rossz haláltípusok. A csecsemők és a sokgyerekes apukák sorsa például kedvezőbb volt az alvilágban, a balesetben meghalt emberek helyzete viszont rosszabb. ${ }^{52}$ Az alvilágba került lelkek sorsának leghíresebb összefoglalója a Gilgameš, Enkidu és az alvilág címủ müben található, de ráolvasásokban is felsorolnak különböző rossz haláltípusokat, mint - Dumuzi számára is releváns példát idézve - a pusztában való temetetlen halál, valamint a házasság és a családalapítás előtti halál. ${ }^{53}$ Dumuzit kétszer is úgy nevezik, mint akinek nincs háza: egyszer a démonok (53. sor): „Egy ember, akinek nincs saját háza, és jó az élete - ki látott már ilyet?”, másodjára a narrátor (70. sor): „A férfi felé, akinek nincs háza, felé tartották a baltát”. Más Dumuzi-szövegekben nem találkoztam ezzel az epithetonnal, ezért a jelen esetben egyedi értelmezésről vagy jobban mondva hangsúlyról lehet szó, már ami Dumuzi halálát illeti.

${ }^{49}$ Alster: i. m. (3. jegyz.).

${ }^{50}$ Sladek: i. m. (4. jegyz.).

${ }^{51}$ Volk: i. m. (4. jegyz.).

${ }^{52}$ A Gilgameš, Enkidu és az alvilág című költeményben lásd A. Gadotti: Gilgamesh, Enkidu, and the Netherworld and the Sumerian Gilgames Cycle. Boston - Berlin 2014; J. Bauer: Der „schlimme Tod” in Mesopotamien. In Dumu-E -Dub-BA-A. Studies in Honor of Åke W. Sjöberg. Eds. H. Behrens - D. Loding M. T. Roth. Philadelphia 1989. 21-27.

${ }^{53}$ Gadotti: i. m. (52. jegyz.). További példák: M. J. Geller: Evil Demons: Canonical Utukku Lemnūtu Incantations. Introduction, Cuneiform Text, and Transliteration with a Translation and Glossary. Helsinki 2007. Tablet IV: 131-136. sor; B. Alster: Edin-na ú-sag-gá: Reconstruction, History, and Interpretation of a Sumerian Cultic Lament. In: Keilschriftliche Literaturen. Ausgewählte Vorträge der XXXII. Recontre Assyriologique Internationale Münster, 8.-12.7.1985. Hrsgg. K. Hecker - W. Sommerfeld. Berlin 1986. 22; W. G. Lambert: The Theology of Death. In: Death in Mesopotamia. Papers Read at the XXVIe Rencontre assyriologique internationale. Ed. B. Alster. Copenhagen 1980. 57. 
A Dumuzi és Ĝeštinanna gyaníthatóan intertextuális vonatkozásokkal is rendelkezik. A második sorban Inana istennő öléhez mennek a démonok. A megfogalmazás eléggé meglepő, mivel Inana öléhez a férje, Dumuzi szokott menni a szent nász szövegekben. ${ }^{54}$ Talán ez is egy szemrehányás Inana részére az ötödik sorral együtt, amelyben az „alvilágra vágyott”. Normális esetben Inana földi férjeire használják ezt a kifejezést, a királyokra, akik az istennő „szívének választottjai”. ${ }^{5}$ A szöveg „szerzője” így burkoltan Inana nem megfelelö irányultságú vágyaira utalt, ami a férje halálát okozta.

Végül, ha összehasonlítjuk a Dumuzi és Geštinanna, valamint az Inana alvilágjárása szöveget, úgy tűnhet, hogy a két szöveget összekapcsoló elméletek ellenére az Inana alvilágjárásának határozottan érthetőbb a nyelvtana, 412 soros, mindent nyugodtan kifejtve és elég időt hagyva elmond, nem olyan tömör, mint a tárgyalt elbeszélésünk. Az Inana alvilágjárása prózaszerủbb elbeszélés, a Dumuzi és Geštinanna darabosabb, és látványosabban használja a parallelizmust: például a 7-8. sorban „ne vedd fel a ruhád..." és „tedd le a koronád” ellentétekkel cizellálva. Továbbá a Dumuzi és Geštinanna szövegben olyan módon fogalmaztak meg sorokat, hogy azok az átkelésre és a menésre utaló szótagokat vagy szavakat tartalmazzanak. A szöveg több váratlan helyen a DU jelet használja, amelynek jelentése „menni”:

1. 1. sor: „a démon kinyitja a száját” sumerül /ka ba/. A kifejezést többféleképpen írták, a ka - bar, vagy a ka - ba ${ }^{56}{ }^{5}$ illetve egy lexikális listában $\mathbf{k a}-\mathbf{b} \mathbf{b}_{9}-\mathbf{r e}_{6}$ jelekkel. ${ }^{57}$ A ba(/d.r) igei elemmel viszonylag ritka, a ka $\hat{\mathbf{g a l}}_{2}-\mathbf{t a k a}_{4}$ sokkal gyakoribb. Itt nem a ba vagy a bar jeleket használták, hanem a bad-re ${ }_{6}$ olvasatúakat, amelyeket a BAD.DU jelekkel kell írni. ${ }^{58}$

gal $_{5}-\mathbf{l a}_{2}$ tur ka ba-a-ši-ba $(\mathrm{BAD})-\mathbf{r e}_{6}(\mathrm{DU})$ gal $_{5}-\mathbf{l a}_{2}$ gu-la-ra gu $\mathbf{g u}_{3}$ mu-na-de $\mathbf{2}_{2}-\mathbf{e}$

2. 5. sor: az Inana leszállása az alvilágba ismételten az al dug ${ }_{4}$ kifejezést használja, mikor azt mondják, hogy „arra vágyott”(191-194. sor).

ETCSL 1.4.1. 192. ['inana] an gal al $\mathbf{b i}_{2}{ }_{2}$-in-dug ${ }_{4} \mathbf{k i ~ g a l ~ a l ~} \mathbf{b i}_{2}$-in-dug ${ }_{4}$ „Inana a nagy égre vágyott, a nagy földre vágyott".

Itt a ša $\mathbf{s}_{3}-\mathbf{g e}_{4}-\mathbf{d e}_{6}$ 'vágyni valamire' szinonimája szerepel, amelyben a de ${ }_{6}$ a DU jel.

4. ga $_{2}$-nu dinana kaskal-zu-še ${ }_{3}$ ni-ba ĝen(DU)-na kur-še ${ }_{3} \underline{\text { ed }}_{3}\left(D U_{6} \cdot \underline{D U}\right)-$ de $_{3}$

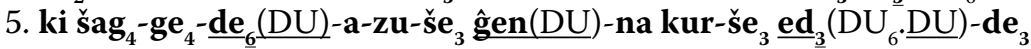

„Gyere Inana, egymagad gyere az utadra, menj le az alvilágba!

Menj arra helyre, amire úgy vágytál, menj le az alvilágba!"

${ }^{54}$ Sefati: i. m. (32. jegyz.).

${ }^{55}$ H. L. J. Vanstiphout: Lipit-Eštar's Praise in the Edubba. JCS 30 (1978) 36 és 41: 16. sor; A. Falkenstein: Zu den Inschriftenfund der Grabung in Uruk-Warka 1960-1961. BagM 2 (1963) 80: Anam A 8. sor.

${ }^{56}$ A kifejezéshez lásd F. Karahashi: Sumerian Compound Verbs with Body-Part Terms. Chicago 2000. 128; vagy M. E. Cohen: Sumerian Hymnology: The Eršemma. Cincinnati 1981. 91-91: 173'; J. Krecher: Sumerische Kultlyrik. Wiesbaden 1966. 190: V 38.

${ }^{57}$ Materials for the Sumerian Lexicon XVI: 76: 4-7. sor.

${ }^{58}$ Több példát nem ismerek BAD jellel. 
3. 29. és 34. sorok a Dumuzi álmában is megjelennek (176-177. sor sig $\left.{ }_{10}\right)$ és az Inana leszállása az alvilágba szövegben is (373-374. és 377-378. sor): Utu gazella kezet és lábat ad neki. Mindkét szövegben a šum ${ }_{2}$,adni” szóval.

Dumuzi álma ETCSL 1.4.3. 176-177. sor: šu-ni šu maš-da $\mathbf{a}_{3} \mathbf{u}_{3}$-mu-ni-in-šum $\mathbf{m}_{2} /$

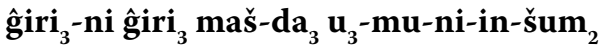

Inana alvilágjárása ETCSL 1.4.1. 373-374. sor: šu-ĝgu $\mathbf{~}_{\mathbf{1 0}}$ šu muš-a $\mathbf{u}_{\mathbf{3}}$-mu-ni-in-

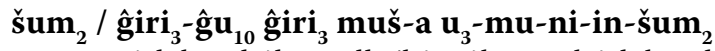

„Kérlek, adjál gazella/kígyókezet, kérlek, adjál gazella/kígyólábat”

Itt a kur ${ }_{2}$ és a bal szó olvasható az átváltozásnál.

šu-ĝa ${ }_{2} \mathrm{u}_{3}$-mu-e- $\underline{\mathrm{kur}}_{2}$ ulutim ${ }_{2}-\hat{\mathrm{g}} \mathrm{u}_{10} \mathrm{u}_{3}$-mu-e- $\underline{\mathrm{bal}}$

„Változtasd át a kezem, kérlek, változtasd át az alakom, kérlek!”

A kur ${ }_{2}$ és a bal nemcsak átváltozást jelent, hanem átkelést is, ráadásul a kur ${ }_{2}$,átváltoztat" úgy hangzik, mint a kur ${ }_{1}$ "alvilág”, „idegen ország” szó. ${ }^{59}$ A két fő szövegben a kezet és a lábat változtatja át, itt az ulutim 2 „forma, alak” szó szerepel, ami sokkal választékosabb, és a jel is látványosabb: ${ }^{60}$

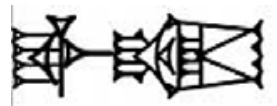

3. ábra. Az ulutim 2 jel

4. 35. sor: a menekülés hasonlatában a kígyó átkelése ismét a 'bal' igével történik a hegyek mezőin. A helyszín, a mező pedig šag -tum $_{2}$, amelyben a tum ${ }_{2}$ a DU jel.

muš saĝ-kal-gin $\check{\text { šag }}_{4}$-tum $_{2}$ (DU) hurur-saĝ-ĝ $\mathbf{a}_{2}$ mu-ni-in-bal-bal

„Mint a kígyó, ami a hegyek mezőin átkel”.

5. 55. sor: a démonok emesal dialektusban szólalnak meg, és úgy beszélnek Dumuziról, a pásztorról. Az emesal általában női szociolektus irodalmi szövegekben. A standard sumer pásztor szó sipad, az emesal verziója su $\mathbf{s u}_{8}$-ba-ra. A su $\mathbf{s u}_{8}$ két DU jellel írandó. A szövegben csak az emesal szót használják, ha pásztornak nevezik Dumuzit. (Minden egyéb esetben úgy hivatkoznak rá, hogy „az ifjú”)

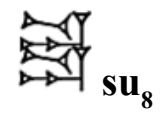

4. ábra. A su $\mathbf{s u}_{8}$ olvasatú jel

${ }^{59}$ Alster: i. m. (7. jegyz.) 26. jegyz.: kur „alvilág, idegen ország” szóra való allúzió más szövegben is előfordul. Frahm: i. m. (11. jegyz.) 76. További példa az ugyanolyan hangzású szavak használatára: B. Alster: Paradoxical Proverbs and Satire in Sumerian Literature. JCS 27 (1975) 209: du „menni” vagy du „mondani”.

${ }^{60}$ Kép: http://psd.museum.upenn.edu/nepsd-frame.html uludin lemma alatt. 


\section{Összefoglalás}

Modern nyugati értelemben vett értekezések, esszék és kommentárok nem voltak az ókori Mezopotámiában, emiatt csak közvetve lehet kikövetkeztetni, hogy milyen elméletek állhattak az ókori mezopotámiaiak szellemi tevékenysége mögött. Az óbabiloni korban a lexikális listáknál már láthatóan megjelennek kommentárok és hermeneutikai értelmezések. ${ }^{61}$ A szakirodalom az ókori Mezopotámiában a listákat nevezte ki a „tudományos müfajnak”, és a tudományos gondolatok megnyilvánulási formájának. ${ }^{62}$ A Dumuzi és Ĝeštinanna szöveg viszont felveti a kérdést, hogy itt vajon nem a narratív szövegbe füzték-e bele az elméletet a jelek szintjén. A 16. sor szemmel láthatólag mutatja, hogy speciális jeleket válogattak ki hozzá: rengeteg más gyakoribb fegyvernevet is írhattak volna. A többi példa pedig talán nem véletlenül összpontosul a járásra, átkelésre, átváltozásra utaló szavakra és jelekre. Ennek megfelelően a szöveg vezérmotívuma az átkelés lenne, amit Dumuzi foglalkozása, a pásztor szó emesal megfelelője $\left(\mathbf{s u}_{\mathbf{8}}-\mathbf{b a}\right)$ az ékírásos jelekben magába foglal.

Amennyiben ez a feltevés lehetséges, akkor Dumuzi történetének ókori recepciója Alster értelmezését támasztja alá, miszerint Dumuzi átmeneti figura az élet és a halál, az emberek és az istenek között, a pusztához tartozik, a szimbolikus átmeneti területhez.

\section{Fordítás}

A szöveg beszédet bevezető formulával kezdődik. Rögtön a galla-démonok ${ }^{63}$ beszédét $^{2}$ olvashatjuk, akik Uruk városába mennek, hogy Inanát (vissza?)vigyék az alvilágba. Inana öltözékének a felsorolása utalás az Inana alvilágjárásának az elejére, amelyben részletesen leírják, hogy felvette az öltözékét, az ékszereit és a sminkjét. A felszerelés különös jelentőséggel bír: ezek testesítik meg Inana isteni erejét. Ezután Inana elég gyorsan felajánlja Dumuzit a démonoknak. A démonok a fegyvereiket készítik elő, és Dumuzit kínozzák. Dumuzi Utuhoz, a napistenhez imádkozik, hogy mentse meg. A rokoni szálakra hivatkozik, valamint Utu feladatkörére, az igazság biztosítására, és kéri, hogy változtassa át. Dumuzi a húgához, Geštinannához menekül, aki siratni kezdi. A galla démonok megbeszélik egymással, hogy Dumuzi biztosan a nővéréhez fog menekülni, és ezért ők is odamennek. A barát és a sógor említése az 54. sorban utalhat a hosszabb $D u$ muzi álma szövegre, amelyben Dumuzi barátjának árulása külön epizódban szerepel:

${ }^{61}$ Crisostomo: i. m. (11. jegyz.).

${ }^{62}$ W. von Soden: Leistung und Grenze sumerischer und babylonischer Wissenschaft. Darmstadt 1965. 21-59; N. Veldhuis: History of the Cuneiform Lexical Tradition. Münster 2013. 2-5; M. Van de Mieroop: Theses on Babylonian Philosophy. JANEH 5 (2018) 15-39. A tudományos szövegeik formája a lista volt. Ez azt jelenti, hogy a szisztematikus elméleteiket (szavakból, jelekből illetve protasisból és apodosisból álló) listák formájában összegezték, és nem esszékben.

${ }^{63}$ A galla eredetileg csendőrszerủ foglalkozást jelölt. 
a barát elmondja a démonoknak, hogy Dumuzi hová bújt. A húga, Ĝeštinanna azonban a démonok kínzása ellenére sem árulja el a bátyja rejtekhelyét. Ettől függetlenül a démonok kitalálják, hogy Dumuzi az istállóba ment, és ott végül elfogják. A szöveg végén Geštinanna a bátyja keresésére indul.

1. A kis galla kinyitotta a száját, és a nagy gallához szólt:

2. „Gyerünk, a fényes Inana öléhez menjünk!”

3. A gallák, amint megérkeztek Urukba, megragadták a fényes Inanát.

4. „Gyere Inana, egymagad gyere az utadra, menj le az alvilágba!

5. Menj arra helyre, amire úgy vágytál, menj le az alvilágba!

6. Menj Ereškigal ${ }^{64}$ földjére, menj le az alvilágba!

7. A fényes ruhád, az úrnői ruhád inkább ne vedd fel, menj le az alvilágba!

8. A fényes koronád, a dicsőséged jelvényét rakd le a fejedről, menj le az alvilágba!

9. Ne fesd ki a szemed, menj le az alvilágba!

10. A lábadra xx[ ne] kösd fel, menj le az alvilágba!

11. Mikor te lemész [ ] nem nyúl"

12. A fényes Inanát elengedték, [ ]

13. Inana Dumuzit adta a kezükbe maga helyett.

14. „Az ifjúnak <bilincsbe > verjük a lábát,

15. ejtsük csapdába az ifjút, tegyünk rá nyakörvet!"

16. Kelevéz, véső, hatalmas lándzsa meredt felé,

17. nagy baltákat élesítettek,

18. az ifjút felállították, leültették.

19. „Dobjunk kötelet a vállára, állítsunk gyilkost (elé)!”

20. Az ifjúnak megkötözték a kezét - három (?) kötéllel tették,

21. a saját ruháját az arcára borították.

22. Az ifjú Utuhoz az ég felé emelte kezét:

23. „Utu, a barátod én vagyok. Fiatal vagyok, ismerlek téged,

24. aki elvette feleségül a nővéred.

25. Ö lement az alvilágba,

26. mivel ő lement az alvilágba,

27. én helyettesként az alvilágnak lettem adva.

28. Utu, az igazság bírója te vagy, hadd ne legyek elkapva!

29. Változtasd át a kezem, kérlek, változtasd át az alakom, kérlek!

30. Hadd csússzak ki a gallák kezei közül, el ne kapjanak!

31. Mint kobra, ami átkel a hegyek mezőin,

32. hadd meneküljek a nővéremhez, Geštinannához!"

33. Utu elfogadta a könnyeit,

34. a kezeit átváltoztatta, az alakját átalakította.

35. Mint kobra, ami a hegyek mezőin átkel,

${ }^{64}$ Az alvilág úrnője, Inana nővére. 
36. Dumuzi, mint madár, ami a sólyom karmából elrepült, az életét mentette,

37. Geštinannához menekült.

38. Geštinanna, amint meglátta a testvérét,

39. az arcát karmolta, az orrát karmolta,

40. az arcát befedte, a ruháját felkötötte.

41. Az elátkozott ifjúnak sirató dalt mondott:65

42. „Ó, a bátyám, ó, a bátyám, az ifjú, akinek a napja még nem [telt be],

43. ó, a bátyám, a pásztor Amaušumgalanna, akinek a napja nem telt be,

44. ó, a bátyám, az ifjú, akinek nincs felesége, nincs gyereke,

45. ó, a bátyám, akinek nincs barátja, akinek nincs társa,

46. ó, a bátyám, akinek a szépségét az anyja nem látja!"

47. A gallák keresték, és körbevették Dumuzit.

48. A kis galla ezt mondja a nagy gallának:

49. „A gallákban nincs együttérzés, nincs apjuk, anyjuk, bátyjuk, nővérük, gyerekük,

50. amióta az embereket elhelyezték, és az ég és a föld eltávolodott,

51. ti, gallák vagytok, akik az embert, mint nádkerítés, [közrefogják].

52. Nem kegyelmeznek, a jót és a rosszat nem ismerik.

53. Egy ember, akinek nincs saját háza, és jó az élete - ki látott már ilyet?

54. Nem a barátjához fog menni, nem a sógorához fog menni,-

55. Geštinannához menjünk a pásztorért!"

56. A gallák összegyültek és keresték.

57. Még a száján volt a siratója,

58. mikor a gallák Geštinannához megérkeztek.

59. „Mutasd meg, hol van a bátyád!” mondták, de (ő) nem szólt egy szót sem.

60. A saját haját adták az ölébe, de nem szólt egy szót sem,

61. a saját kezével karmoltatták az arcát, de nem szólt egy szót sem,

62. a saját kezével tépették a ruháját, de nem szólt egy szót sem,

63. port öntöttek az ölébe, de nem szólt egy szót sem.

64. Dumuzit Geštinanna házában nem találták.

65. A kis galla ezt mondta a nagy gallának:

66. „Menjünk a fényes istállóba, gyerünk!”

67. Dumuzit a fényes istállóban elkapták.

68. Bekerítették, és [ elfo]gták,

69. keresték és meglátták.

70. Az ifjú felé, akinek nincs háza, nekiszegezték a baltát,

71. a tőrt már élesítették, kerítéssel körbevették.

72. A nővér a bátyja sorsa miatt, mint madár, kőrözött a városban:

73. „Bátyám, nyomorult! ${ }^{16}$ Hová menjek? Bárkinek a házába bemegyek!”

${ }^{65}$ A fordításban szereplő „elátkozott” és „sirató” szavak az eredeti szövegben ugyanúgy vannak: sumerül ni $\hat{g}_{2}$-gig-ga, „bünös”, „tabu alatt álló”, „szerencsétlen”, valamilyen dolog, ami a rituális tisztaságot sérti.

${ }^{66}$ Ismételten ni $\hat{\mathbf{g}}_{2}$-gig-ga. 


\title{
SUMMARY
}

The text Dumuzi and Geštinanna belongs to the problematic group of Sumerian narratives. A possible explanation for the unusual formulations in the text might be the attempt of an ancient scribe to comment on the problems of the stories of the god Dumuzi, which was adjusted to the form of the narrative text. The "author" summarized theological questions in an implicit way, with hermeneutical techniques. The special use of cuneiform signs is one such example applied to refer to the nature of Dumuzi. Also, many other formulas appear in the text, which intertextually allude to the relationship of Dumuzi, the king, and Inana.

Keywords: Dumuzi-Tammuz, Sumerian literature, hermeneutics, intertextuality, Old-Babylonian religion

\author{
Pintér Anna Krisztina \\ annakrisztina4@gmail.com \\ ELTE Asszíriológiai és Hebraisztikai Tanszék \\ 1088 Budapest, Múzeum krt. 4/F
}

A cikk a Creative Commons Attribution 4.0 International License (https://creativecommons.org/ licenses/by/4.0) feltételei szerint publikalt Open Access közlemény, melynek szellemében a cikk bármilyen médiumban szabadon felhasználható, megosztható és újraközölhető, feltéve, hogy az eredeti szerző és a közlés helye, illetve a CC License linkje és az esetlegesen végrehajtott módosítások feltüntetésre kerülnek. (SID_1) 